\title{
TAONGA, RIGHTS AND INTERESTS: SOME OBSERVATIONS ON WAI 262 AND THE FRAMEWORK OF PROTECTIONS FOR THE MĀORI LANGUAGE
}

\author{
Māmari Stephens*
}

In October 2010 the Waitangi Tribunal released the first chapter of its long-awaited report of the WAI 262 enquiry into indigenous flora and fauna and Māori intellectual property. This chapter focuses on aspects of the claim relating to the Māori language and critiques the development of Māori and Crown generated initiatives to protect and revitalise te reo Māori, including the Māori Language Strategy (Te Rautaki Reo Mãori). The Tribunal argues that the Crown must ultimately become Māori speaking. Consideration of this report and the legal protections in place for the Māori language reveals a framework that is incoherent, and largely incapable of achieving the Tribunal's goal, or even of fully protecting what the Tribunal described as "a taonga of quite transcendent importance".

But even describing te reo as a taonga understates its importance. The language is clearly a taonga of quite transcendent importance to Māori, and few other taonga could rival its status. Without it, Māori identity would be fundamentally undermined, as would the very existence of Māori as a distinguishable people. $^{1}$

In October 2010 the Waitangi Tribunal released the first chapter of its long-awaited report of the WAI 262 enquiry into indigenous flora and fauna and Māori intellectual property ("2010 Report"). Arguably the WAI 262 claim itself has had "no equal in terms of significance to Maori since the te

* Māmari Stephens (Te Rarawa) is a lecturer in law and co-leader of The Legal Māori Project at the Faculty of Law at Victoria University of Wellington in New Zealand. The Project is also co-led by Dr Mary Boyce from the University of Hawai'i at Manoa.

1 Waitangi Tribunal Te Reo Māori - Pre-publication (WAI 262 2010) 48. "Te reo Māori" translates as "the Māori language". 
reo Māori claim...". ${ }^{2}$ With such expectation, this chapter is a critically important first instalment in the report on that claim, particularly in view of its focus. The chapter focuses on aspects of the claim relating to the Māori language ("te reo Māori") and offers a critical snapshot of the development of Māori and Crown generated initiatives to protect and revitalise te reo Māori. It critiques the Government's Māori language strategy ("Rautaki Reo Māori") and the performance of the lead agencies in implementing that strategy. In addition, the report synthesises recent survey data and evaluates the relative health of te reo Māori, rightly skewering some unwarranted claims of recent success in Māori language revitalisation. The report, as might be expected, also offers some important, albeit provisional, recommendations for future developments.

The Tribunal in the 2010 Report affords little space to an effective critique of the legislative scheme as underpinned by the well-outdated Māori Language Act 1987. In view of the importance of the legislative framework in the implementation of the protection and revitalisation of te reo Māori, this understated approach is surprising. The Tribunal does not, for example, recommend substantive amendment of the Māori Language Act 1987 beyond enhancing the role of Te Taura Whiri i te reo Māori (the Māori Language Commission).

In addition the 2010 Report utilises a different rhetoric to the Waitangi Tribunal's Te Reo Māori Report of $1986 .{ }^{3}$ In 1986 the Tribunal used an explicit rights-based discourse to explain and argue for effective protection of the Māori language. The 2010 Report avoids a rights-based discourse almost entirely. What is required is less a focus on rights protections for an important linguistic minority, but an entire shift in self perception: ${ }^{4}$

Fundamentally, there is a need for a mindset shift away from the pervasive assumption that the Crown is Pākehā, English-speaking, and distinct from Māori rather than representative of them. Increasingly, in the twenty-first century, the Crown is also Māori. If the nation is to move forward, this reality must be grasped. If the Crown is serious about preserving and promoting the language it must also endeavour to speak te reo itself. This not only leads by example but provides symbolic as well as tangible support to keeping the language alive. Māori should be able to use their own language, given its official status, in as many of their dealings with the New Zealand State as practicable - particularly since the public face of the Crown will often be a Māori one. The idea of the Crown speaking Māori is of course not novel ; by necessity, this was the status quo for a large proportion of New Zealand's colonial past.

This paper argues that such a shift cannot yet be achieved, in part because the necessary protections put in place for the Māori language as a taonga under Article II of the Treaty of

2 Maui Solomon "The Wai 262 Claim: A Claim by Māori to Indigenous Flora and Fauna: Me o Rātou Taonga Katoa" in Michael Belgrave, Merata Kawharu and David Williams (eds) Waitangi Revisited: Perspectives on the Treaty of Waitangi (Oxford University Press, Auckland, 2005) 213 at 213.

3 Waitangi Tribunal Te Reo Māori Claim (WAI 11 1986).

$4 \quad$ Waitangi Tribunal Te Reo Māori-Pre-publication, above n 1, at [5.4.6(2)]. 
Waitangi are incoherent and largely ineffective, precluding the use of Māori in the civic realm. Despite the language's legally recognised status as a taonga, the statutory rights, set out in the Māori Language Act 1987 obstruct rather than facilitate the use of Māori in legal as well as more broadly civil contexts. There is some cause for hope, particularly now Māori is used in Parliament, but a Māori speaking Crown is, as yet, a hope, not yet a reality.

\section{THE MĀORI LANGUAGE AS TAONGA}

The critically important starting point for the protections now in place for the Māori language was the recognition that an intangible entity such as language was indeed a taonga for the purpose of the Treaty of Waitangi. Identification of any object or property tangible or intangible, triggers the guarantees in art 2 of the Treaty of Waitangi (with the author's emphasis):

Ko te tuarua

Ko te Kuini o Ingarani ka wakarite ka wakaae ki nga Rangitira ki nga hapu - ki nga tangata katoa o $\mathrm{Nu}$ Tirani te tino rangatiratanga o o ratou wenua o ratou kainga me o ratou taonga katoa. Otiia ko nga Rangatira o te wakaminenga me nga Rangatira katoa atu ka tuku ki te Kuini te hokonga o era wahi wenua e pai ai te tangata nona te Wenua - ki te ritenga o te utu e wakaritea ai e ratou ko te kai hoko e meatia nei e te Kuini hei kai hoko mona.

Her Majesty the Queen of England confirms and guarantees to the Chiefs and Tribes of New Zealand and to the respective families and individuals thereof the full exclusive and undisturbed possession of their Lands and Estates Forests Fisheries and other properties which they may collectively or individually possess so long as it is their wish and desire to retain the same in their possession; but the Chiefs of the United Tribes and the individual Chiefs yield to Her Majesty the exclusive right of Preemption over such lands as the proprietors thereof may be disposed to alienate at such prices as may be agreed upon between the respective Proprietors and persons appointed by Her Majesty to treat with them in that behalf.

The Waitangi Tribunal, Parliament, and the courts of New Zealand, have all affirmed that the Māori language is, and was, a taonga for the purposes of art 2, and therefore subject to the guarantee of tino rangatiratanga in the Māori language version of the Treaty, as well as to the guarantee of full exclusive and undisturbed possession, as set out in the English version of the Treaty. That particular acceptance of the Māori language as a taonga for the purposes of the Treaty of Waitangi only came after a combination of events in the 1960s, 1970s and 1980s brought the plight of the language to the foreground of public attention. Such events included the Māori Language Petition of 1972, signed by 30,000 people, which requested that Māori language be offered in all schools, and the Land March of 1975. Other political actions were carried out by activist groups such as Ngā Tamatoa, and societies for the protection of the language such as the Reo Māori Society, and the Wellington Māori Language Board, Ngā Kaiwhakapūmau i te Reo. In 1984 Ngā Kaiwhakapūmau i te Reo lodged a claim (WAI 11) before the Waitangi Tribunal. The Waitangi Tribunal subsequently 
found in its 1986 report that the language was a taonga and as such, the Crown was bound by certain obligations, as a Treaty partner: ${ }^{5}$

The evidence and argument has made it clear to us that by the Treaty the Crown did promise to recognise and protect the language and that that promise has not been kept. The 'guarantee' in the Treaty requires affirmative action to protect and sustain the language, not a passive obligation to tolerate its existence and certainly not a right to deny its use in any place. It is, after all, the first language of the country, the language of the original inhabitants and the language in which the first signed copy of the Treaty was written.

The term taonga defies any exhaustive definition, and in summing up the findings of a number of Tribunal reports the Tribunal stated in the Petroleum Report of 2003 that: $^{6}$

Though the term has a number of other more mundane meanings, successive carefully reasoned reports of the Tribunal over many years now have come to treat 'taonga', as used in the Treaty, as a tangible or intangible item or matter of special cultural significance. ${ }^{7}$

On the other hand the Tribunal has declined to extend the status of taonga to institutions or technologies used to protect or promulgate the language, reserving that status for the language (and its dialects) alone. So, claims for taonga status to be extended to wānanga and the radio spectrum, therefore, have failed before the Waitangi Tribunal. ${ }^{8}$

The courts have also acknowledged that the status of taonga applies to the tangible and intangible, accepting both language and familial organisation as examples of intangible taonga. ${ }^{9}$ Lord Woolf of the Privy Council followed the approach of the Court of Appeal as well as the Tribunal in the final Broadcasting Assets decision: ${ }^{10}$

The Maori language (Te Reo Maori) is in a state of serious decline. It is an official language of New

Zealand, recognised as such by the Maori Language Act 1987. It is "a highly prized property or treasure

5 Te Reo Māori Claim, above n 3, at [4.2.4].

6 See Waitangi Tribunal The Petroleum Report (WAI 796, 2003) at [5.3].

7 See for example Waitangi Tribunal Report of the Waitangi Tribunal on the Kaituna River Claim: (WAI 4, 1984) at [4.7]; Waitangi Tribunal Motunui Waitara Report (WAI 6, 1983) at [8.3(3)]; Waitangi Tribunal Report of the Waitangi Tribunal on the Muriwhenua Fishing Claim (WAI 22, 1988) at [10.22].

8 See Waitangi Tribunal Allocation of Radio Frequencies Report (WAI 26, 1990) at [8.3]; Waitangi Tribunal Wānanga Capital Establishment Report (WAI 718, 1999) at [5.6] and [2.1].

9 See in respect of language see New Zealand Māori Council v Attorney-General HC Wellington CP942/88, 3 May 1991; New Zealand Mãori Council v Attorney-General [1987] 1 NZLR 641 (CA) and [1994] 1 NZLR 513 (PC); in respect of familial organisation see Barton-Prescott v Director-General of Social Welfare [1997] 3 NZLR 179 at 184

10 New Zealand Māori Council v Attorney General [1994] 1 NZLR 513 (PC) at 513. 
(taonga) of Maori" (Cooke P [1992] 2 NZLR 576, at p 578 in the Court of Appeal) and it is also part of the national cultural heritage of New Zealand.

The approaches taken by the Waitangi Tribunal and the courts have not been entirely consistent, with the courts having dealt more conservatively with the idea of taonga. The courts on the one hand, have accepted the notion that a river can be a taonga, but they have not accepted that iwi can use the taonga to generate electricity. ${ }^{11}$ The Waitangi Tribunal, on the other hand, has accepted that the taonga of geothermal resources could indeed provide the basis of a right to generate electricity. ${ }^{12}$ In addition, New Zealand courts have also floated the idea that taonga may not necessarily be held by Māori, made by Māori or hold any Māori content or association. ${ }^{13}$

In view of the lack of a consistent definition or approach in legislation and in view also of divergent directions taken in the identification and protection offered to taonga in the Waitangi Tribunal and the courts, it may not be surprising that New Zealand law has not coherently recognised the status of one specific taonga - the Māori language - within its framework.

\section{LANGUAGE AS TAONGA - THE WAITANGI TRIBUNAL}

The 1986 Tribunal, in its landmark report that set the ball rolling for recognition of the Māori language as a taonga, used the language of rights in determining the nature of the protections that ought to be afforded the language. The Tribunal stated that the guarantee under Article II extended to protect a general "right to use the Māori language". The Tribunal did not throw much light on the precise extent to which the Treaty itself could be considered the source of this general right to the Māori language, as opposed to being declarative of pre-existing rights: ${ }^{14}$

Taking the two versions side by side it will become at once apparent that the Maori guarantee is significantly wider than the English version of that guarantee, which leads us to say that the right to use the Maori language would have been one of the rights expected to be covered by the Royal guarantee by those chiefs who signed the Treaty. Taking into account all the circumstances as they existed when the bargain was made we think that it is unlikely that many Maori signatures would have been obtained if it had been said by Captain Hobson that the Royal guarantee of protection would not include the right to use Maori in any public proceedings involving a Maori.

11 Te Runanganui o Te Ika Whenua Inc Society v Attorney-General [1994] 2 NZLR 20 (CA) at 24.

12 Waitangi Tribunal Preliminary Report on the Te Arawa Representative Geothermal Resource Claims (WAI 153, 1993) at [4.4]. For more discussion on the consistencies and inconsistencies between the courts and the Tribunal in their approach to taonga see Arla Kerr "Taonga as Treaty Concept: the Approaches of the Courts and the Waitangi Tribunal" (LLB (Hons) Dissertation, Victoria University of Wellington, 2006).

13 See Jacinta Ruru's discussion of the cases of Page v Page (2002) 21 FRNZ 275 and Perry vest HC Auckland CIV-2002-404-002114, 15 December 2003 in Jacinta Ruru "Taonga and Family Chattels" [2004] NZLJ 297.

14 Waitangi Tribunal Te Reo Māori Claim, above n 3, at [4.3.6]. 
Despite its acceptance that the Treaty protects a general right to the Māori language, the 1986 Tribunal was reluctant to be seen as establishing an absolute right to the Māori language as modelled by other countries, such as Wales or Canada. The difference between a general right and an absolute right is not clarified, except that an absolute right would be the outcome of a political or judicial process from which the Tribunal appears keen to distance itself. The Tribunal appeared be trying to allay fears that its conception of a general right might lead immediately to unlimited public expenditure or indeed a politically problematic privileging of the Māori language in the public sphere: ${ }^{15}$

The creation of absolute rights to use the language is however a political or judicial response to the issue. We could go further and promote for example, the Canadian model, which requires full bilingualism in all official documents. We do not think that approach is entirely appropriate to our New Zealand way or the principles of the Treaty whereby greater cultural sensitivity may be sought, not by prescriptive laws, but in an appeal to the strong New Zealand sense of fair play. Official recognition is one thing but popular recognition will depend upon successful establishment of a body to promote the language for both Maori people and New Zealanders as a whole, to watch over progress and suggest strategies that overcome the difficulties that are bound to arise.

Regardless of its reluctance to be seen as promulgating an absolute right, the Tribunal clearly determined that the Crown was under an obligation to protect the Māori language on the basis of the Treaty-based guarantee. At the heart of some of the most influential submissions before the Tribunal was the notion that the recognition of te reo Māori should be progressively realised. The Tribunal placed significant weight on the submissions of the New Zealand Section of the International Commission of Jurists as presented by the late Martin Dawson in regard to the interpretation of the word guarantee within the Treaty text: ${ }^{16}$

... the point was made that the word denotes an active executive sense rather than a passive permissive sense, or in a phrase "affirmative action". To quote from the submission: "By these definitions therefore, the word (guarantee) means more than merely leaving the Māori people unhindered in their enjoyment of their language and culture. It requires active steps to be taken to ensure that the Māori people have and retain the full exclusive and undisturbed possession of their language and culture ...

Also in evidence before the Waitangi Tribunal, Secretary for Justice, Stanley Callaghan appears to acknowledge that the duty was to be progressively realised and should not be frozen when exercised specifically within the courts. The correlative of the duty was, in his language, a right, albeit a limited one: ${ }^{17}$

15 Ibid, at [8.2.9].

16 Te Reo Māori Claim, above n 3, at [4.2.7].

17 Te Reo Māori Claim, above n 3 at [8.2.4] [emphasis added]. 
... the Department accepts that it would be practicable and not prohibitively expensive to proceed along the lines of the Welsh Language Act provided that the right given is limited for the time being to a right to address the Court or give evidence in Māori. This would exclude an obligation to provide for transcripts and court documents in Māori as a consequence ... The time has come for change and we look forward to these developments as representing an important forward step in recognising the deepseated wish of many Māori people for their language and culture to flourish through its daily use in New Zealand ...

The Māori Affairs Select Committee further developed this notion of progressive realisation in considering the Reo Māori Report and submissions on the Māori Language Bill. They observed that "full recognition of Māori as an official language should be a progressive and gradual policy to be implemented systematically as resources and public acceptance allow". ${ }^{18}$ While this observation surely was intended to deflect criticism for the Bill's failure to adopt all recommendations of the Waitangi Tribunal in the Reo Māori Report, it is also important recognition that the measures comprising official recognition (including official recognition of te reo Māori in the legal system) should not remain in a frozen state.

Despite the Waitangi Tribunal's reluctance to denote an absolute right to the Māori language, the obligation, viewed by the Waitangi Tribunal is a proactive one to protect and sustain the language, imports with it, in Hohfeldian terms, the invariable correlative of a right that accrues not only to individual Māori but to Māori collectives. ${ }^{19}$ As identified by some academic commentators Treaty jurisprudence does reveal a Treaty rights framework and a concomitant set of principles. ${ }^{20}$ However the orthodox view of the Tribunal's role is that it may identify Treaty rights and, importantly, translate those rights into "the vocabulary of the legal paradigm". ${ }^{21}$ This translation process does not usually result in an exhaustive description or analysis of the content of any identified rights. Nonetheless it is evident that the Waitangi Tribunal has often taken the view that the Treaty itself is

18 (9 June 1987) 481 NZPD 9337.

19 Joseph William Singer "The Legal Rights Debate in Analytical Jurisprudence from Bentham to Hohfeld" [1982] Wis L Rev 975 at 986. See also Ed Willis "Legal Recognition of Rights Derived from the Treaty of Waitangi" (2010) 8 NZJPIL 217.

20 See for example Waitangi Tribunal (ed) National Overview: Vol II (Waitangi Tribunal, Wellington, 1997) at 475-494. See also Matthew SR Palmer The Treaty of Waitangi in New Zealand's Law and Constitution (Victoria University Press, Wellington, 2008) at 113-129.

21 PG McHugh "Legal Reasoning and the Treaty of Waitangi: Orthodox and Radical Approaches" in Graham Oddie and Roy W Perrett (eds) Justice, Ethics, and New Zealand Society (Oxford University Press, Auckland, 1999) 99; see also Ed Willis, above n 19, at 6-21. 
a source of Māori rights, particularly of rights that can be determined where other doctrines such as that of aboriginal title may not apply. ${ }^{22}$

\section{LANGUAGE AS TAONGA - LEGISLATION}

Ultimately the Crown's obligations were to be reflected, in part at least, in the Māori Language Act 1987. While the Crown did not adopt all recommendations of the Tribunal, of the five recommendations issued by the Tribunal, the first was directly relevant to supporting and recognising the use of Māori in legal contexts. ${ }^{23}$ The Māori Language Bill was introduced before the WAI 11 report was received by the Crown, but the Act was no doubt enacted, in part, as the Crown's response to the findings of the Waitangi Tribunal and the Māori language claim. It was also enacted in large part to address the findings in Mihaka $v$ Police ${ }^{24}$ that the Māori language had, at the time of that case, no official status in New Zealand and therefore could not be a language used as of right in court proceedings. ${ }^{25}$

The preamble to the Act recognises a duty placed upon it, affirming the Tribunal's approach, in stating that "in the Treaty of Waitangi the Crown confirmed and guaranteed to the Māori people, among other things, all their taonga: and ... the Māori language is one such taonga". ${ }^{26}$ In particular the Act was a legislative response that only addressed the first two of the five recommendations of the Waitangi Tribunal's report. ${ }^{27}$ The other major explicit legislative response to the

22 See for example The Muriwhenua Report, above n 7. See also RP Boast "Treaty Rights or Aboriginal Rights" [1990] NZLJ 33 at 209.

23 See Te Reo Māori Claim, above n 3 at [10.1].

We recommend ... that legislation be introduced enabling any person who wishes to do so to use the Māori language in all Courts of Law and in any dealings with Government Departments, local authorities and other public bodies ...

24 [1980] 1 NZLR 462.

25 See Pakitai Raharuhi v New Zealand (2003) 20 CRNZ 498 (HC) at [41] for the observation that the Māori Language Act 1987 was passed at least in part as a response to Mihaka. Te Ringa Mangu Mihaka, himself has often stated publicly that the case was "the straw that broke the camel's back" in achieving legal recognition of the right to speak Māori.

26 Note that the Preamble of the Māori Television Service (Te Aratuku Whakaata Irirangi Māori) Act 2003 states: "The Tribunal found that the Māori language is an essential part of Maori culture and must be regarded as a taonga, a valued possession."

27 The second recommendation was for the establishment of a supervisory body that came to be known as Te Taura Whiri i te Reo Māori. See Te Reo Māori Claim, above n 3, at [10.2]. Interestingly, a submission by Huirangi Waikerepuru to the Māori Affairs Select Committee considering the Māori Language Bill recounted that a second claim was apparently lodged with the Waitangi Tribunal on the Crown's failure to await the release of the Reo Māori Report before submitting the Māori Language Bill to the House. See Clare Tattersall "A Right to Language? Two Acts" (LLB (Hons) Dissertation, Victoria University of Wellington, 2009) at 27. 
recommendations of the Tribunal (and to subsequent case law) in the Reo Māori Report is the passage of the Māori Television Service Act 2003, a direct response to Recommendation Four; that broadcasting legislation and policy have regard to the Tribunal's finding of the Crown obligation to recognise and protect the Māori language. While it is important to note the likely influence the Reo Māori Report may have had on other legislative developments, such as crucially important amendments to the Education and Broadcasting Acts of 1989, it is equally important to note the limited scope of the Act itself. The Act, including its preamble, must then be read as just one important element of the Crown's legislative recognition of that duty. The mechanisms selected by the Crown to protect the taonga of the Māori language involve allocating official status and consequential statutory rights that provide standing and status to users of the language in very select contexts. Indeed the legislative response obviously dilutes the general right envisaged by the Tribunal.

\section{A Section 3 (Official Status)}

Section 3 of the Act merely states "The Māori language is hereby declared to be an official language of New Zealand". There is little guidance in the Act or elsewhere as to what this status really means. Certainly, this status is a step up from the earlier official recognition afforded Māori under s 77A of the Māori Affairs Act 1953, which was effectively ignored by the Court in the Mihaka case, which refused to countenance that such recognition might extend to a right to speak Māori before the courts. ${ }^{28}$ While denoting Māori as an official language was not one of the recommendations of the Waitangi Tribunal, applying this status appears to have been a response to some of the Waitangi Tribunal's concerns from the Reo Māori Report: ${ }^{29}$

Official recognition must be seen to be real and significant which means that those who want to use our official language on any public occasion or when dealing with any public authority ought to be able to do so. To recognise Māori officially is one thing, to enable its use widely is another thing altogether. There must be more than just the right to use it in the Courts. There must also be the right to use it with any department or any local body if official recognition is to be real recognition, and not mere tokenism.

It is clear from the above extract that the Tribunal did not accept that official language status merely gave rise to a right to use Māori in the courts. This status was also important to enable wide usage in other civil contexts. However, the observations of the Secretary for Justice, Stanley Callaghan, before the Tribunal appeared to view official status only in the context of legal proceedings, although he also viewed such status as an important aim to achieve as a question of (albeit limited) rights or entitlements, and not merely to enable native speakers to be understood: ${ }^{30}$

28 Mihaka v Police, above n 24, at 462-463.

29 Te Reo Mãori Claim, above n 3, at [8.2.8].

30 Ibid, at [8.2.3]. 
... The present interpretative facilities when English is not understood and the various programmes which promote a much greater recognition and understanding of Māori culture do not of course meet the demands of the claimants that the Māori language be given some official status in our courts of law. While the present arrangements may provide for justice to be done in a strict, legalistic sense, a Māori may have an overwhelming sense of grievance and loss of dignity felt through being unable, because of fluency in English, to speak Māori in a court in his own land. That may give rise to such a deep-seated sense of injustice as to prejudice the standing of the courts in some Māori eyes. It seems to us that despite the strict logic of the present situation the time is now appropriate to consider change. Certainly the present situation is at odds with our bicultural foundation at Waitangi in 1840 ...

Indeed the Tribunal's concern to enable the wide use of Māori through effective official recognition is not fully recognised in the Act. No guidance is given within the Act to explain what official status might mean. Judicial determination of the implications of official status has also been limited. Justice Fisher discussed the importance of s 3 in the case of Ngaheu $v$ MAF and concluded that the official status of Māori was a "relevant factor" to be taken into account when determining if the court would use its discretion to allow the submission of Māori language documents; a right not supported by the Act itself. His Honour said: ${ }^{31}$

One [relevant factor to the exercise of the court's discretion] is the declaration in s 3 Māori Language Act that "the Māori language is hereby declared to be an official language of New Zealand" and the long title to the Act which, among other things, declares the Māori language to be an official language of New Zealand. That suggests that although there is no right to file a document expressed in Māori the Courts should be sympathetic to the idea if in the circumstances it would be sensible and practicable to do so.

In this case, at least, official status was considered a relevant consideration in determining use of the court's discretion. In the absence of further judicial determination of what this status actually means, it may well be that the effect of official status of the Māori language will continue to be determined primarily within the courts. This limitation does not reflect the Tribunal's preference that official status be more broadly understood, as described above.

\section{B Section 4 (Rights to Speak Māori in Certain Legal Proceedings)}

Moving on from the official status denoted under s 3, s 4 of the Act creates a statutory right to speak Māori in certain legal proceedings. ${ }^{32}$ It is important to know the exact legal circumstances in which this right can be enforced. Legal proceedings are defined in s 2:

Legal proceedings means-

$31 \quad$ Ngaheu v MAF (1992) 5 PRNZ 201 (HC) at 206.

32 This right is also provided in s 24(g) of the New Zealand Bill of Rights Act 1990. 
(a) Proceedings before any court or tribunal named in Schedule 1 to this Act; and

(b) Proceedings before any Coroner; and

(c) Proceedings before-

(i) Any Commission of Inquiry under the Commissions of Inquiry Act 1908; or

(ii) Any tribunal or other body having, by or pursuant to any enactment, the powers or any of the powers of such a Commission of Inquiry, that is required to inquire into and report upon any matter of particular interest to the Māori people or to any tribe or group of Māori people:

Schedule 1 of the Act sets out the relevant courts and tribunals in which the right can be enforced. All courts are included, but only a small number of tribunals are included. Schedule 1 currently provides for Māori to be used in the following tribunals:

- $\quad$ The Waitangi Tribunal

- $\quad$ The Employment Relations Authority

- The Equal Opportunities Tribunal [now replaced by the Human Rights Review Tribunal]

- $\quad$ The Tenancy Tribunal

- $\quad$ Planning Tribunals [now replaced by the Environment Court]

- $\quad$ Disputes Tribunals established under the Disputes Tribunals Act 1988

Given that the Ministry of Justice now administers 25 tribunals and statutory authorities through its tribunals unit (not including the Waitangi Tribunal as a permanent Commission of Inquiry) this list is small indeed. The circumstances under which the right to use Māori in legal proceedings are also quite circumscribed. As stated in s 4 :

(1) In any legal proceedings the following persons may speak Māori, whether or not they are able to understand or communicate in English or any other language:

(a) Any member of the court, tribunal, or other body before which the proceedings are being conducted

(b) Any party or witness

(c) Any counsel; and

(d) Any other person with the leave of the presiding officer.

(2) The right conferred by subsection 1 of the section to speak Māori does not

(a) Entitle any person referred to in that subsection to insist on being addressed or answered in Māori; or 
(b) Entitle any such person other than the presiding officer to require that the proceedings or any part of them be recorded in Māori.

(3) Where any person intends to speak Māori in any legal proceedings, the presiding officer shall ensure that a competent interpreter is available.

(4) Where, in any proceedings, any question arises as to the accuracy of any interpreting from Māori into English or from English into Māori, the question shall be determined by the presiding officer in such manner as the presiding officers thinks fit.

(5) Rules of court or other appropriate rules of procedure may be made requiring any person intending to speak Māori in any legal proceedings to give reasonable notice of that intention, and generally regulating the procedure to be followed where Māori is, or is to be spoken in such proceedings.

(6) Any such rules of Court or other appropriate rules of procedure may make failure to give the required notice a relevant consideration in relation to an award costs, but no person shall be denied the right to speak Māori in any legal proceedings because of any such failure.

As shown above the right provided under s 4 is a right to speak Māori only. It is not however limited only to the submission of oral evidence or the giving of testimony in the Māori language, as counsel may also use Māori pursuant to s 4 . There has been some judicial determination of the broad application of this right. Under s 4(1) the right to speak Māori in the Court extends not only to those whose first language is Māori but also to any eligible person. In $R v$ Hohua Justice Fisher stated that the rights contained in the Māori Language Act 1987 were not only triggered when the user could demonstrate sufficient disadvantage in the English language: ${ }^{33}$

The significance of section 4 of the Māori Language Act was that it conferred an additional right to speak Māori. This new right did not spring from functional necessity. It was not designed to bring to bridge a gap in the understanding of English. That much is clear from the fact that the right is there

"whether or not they are able to understand or communicate in English..." (s 4(1)). The long title to the

Act commences by describing it as "an Act to declare the Māori language to be an official language of

New Zealand..." I take it that the Act was designed to promote the use of Māori as an end in itself.

It is important not to understate the effects outlined above. By moving away from disadvantage as a prerequisite to access the rights of the Act, the rights, however narrow the application, are unqualified. This and other cases subsequent to the passage of the Act, according to Summer Kupau show that the courts have been co-opted into acting in such a way to preserve the language, rather

$33 R v$ Hohua HC Rotorua T13/90, 24 July 1990. See also $R v$ Hillman [1991] DCR 68. There, the Court recognised the Act was intended to foster the language as a taonga. 
than only acting in respect of the needs of individual petitioners. ${ }^{34}$ Nevertheless, the fact remains that the primary right preserved is only a right to speak, with no formal recognition of a right to submit written documentation in legal proceedings. Such submission may only take place as an exercise of judicial discretion. All such restrictions essentially undermine the Tribunal's original recommendation. Only spoken Māori may be used in the courts as of right, and only before a limited number of tribunals. Written Māori is not protected at all by the Act, and neither written nor spoken Māori is protected in dealings with Government departments, local authorities or other public bodies by this Act. These limitations have been in place and essentially unchanged since 1987. As observed by the Tribunal in 2010, the choice to use Māori in the courts has, in reality, not been made any easier by the existence of the statutory right: ${ }^{35}$

But there are genuine constraints on the exercise of this right for example, the High Court requires at least 10 working days' advance notice of any intention to speak Māori. Under the Maori Language Act, court participants do not have the right to be addressed in Māori and there is no requirement for the proceedings to be recorded in Māori. Even in the Māori Land Court, applicants must inform the registrar of their intention to speak Māori in court so that an interpreter can be arranged. Thus, it is no easier to use Māori in court than any other language besides English. In fact, foreign nationals are catered for by means of interpreters so they can actually communicate and understand proceedings, whereas the ability of Māori court participants to communicate in English is effectively excused by the provisions of the Maori Language Act. It seems to us that this falls short of the intent behind the Tribunal's recommendation in 1986 .

Not only has the right which the 1986 Tribunal envisaged been limited and prescribed over the following 24 years, but there are one or two interesting examples of conflicting enactment of the right that deserve a little more attention.

\section{TE REO MĀORI IN PARLIAMENT}

The legal fora set out in the Māori Language Act 1987 do not include the pre-eminent legal context. Nevertheless Parliament is now one of the few arenas where an effective right does exist to use te reo Māori. In 1985, before the enactment of the Māori Language Act 1987 or the release of the Reo Mãori Report in 1986 the Standing Orders Committee of Parliament made the following statement: ${ }^{36}$

While the standing orders do not prohibit the use of the Maori language in parliamentary proceedings,

the procedures of the House do not encourage such use. Speaker's rulings suggest that a member is

34 Summer Kupau "Judicial Enforcement of 'Official' Indigenous Languages: A Comparative Analysis of the Māori and Hawaiian Struggles for Cultural Language Rights" 26 U Haw L Rev 495 at 519.

35 Te Reo Māori-Pre-publication, above n 1 at [5.4.6(2)(a)].

36 (1 December 1987) 485 NZPD 1416 [emphasis added]. 
expected to address the House in English if he or she can speak that language and that a member using an interpreter cannot have any extension of time for time taken up in making the interpretation

...accordingly the committee recommends an explicit recognition in the standing orders that a member may speak in either English or Maori.

Before this point there had never been a Standing Order to deal with the use of Māori in the House. Speaker's rulings had largely restricted the use of Māori to those who were not fluent in English. Accordingly Standing Order 151 (now 104) was enacted: ${ }^{37}$

\section{Speeches in English or Māori}

A member may address the Speaker in English or in Māori.

This was a bald and unqualified statement of a right to speak Māori in the House. While the context is limited, it is far less bound about by restrictions than the rights to speak granted by the Māori Language Act 1987. The fluency in English of the Members of the House is of no relevance to the exercise of the right, as disadvantage in English is not a pre-requisite for the exercise of the right. As stated by the Speaker in 1997: ${ }^{38}$

When a member speaks in Maori that member does so as of right. Whatever time is allowed by the Standing Orders for that particular type of speech, the whole of that time may be used in Māori. Interpretation into English is for the benefit of members who do not understand Maori and it is in addition to the time for which the member is entitled to speak.

Importantly, the right to speak Māori in the House has been supported by the development of resources to make such a language choice feasible. From December 2009 new simultaneous interpretation services have been made available for any Member who chooses to use Māori in the House. ${ }^{39}$ Evidence from Hansard suggests that the rights regime in Parliament, combined with growing numbers of Māori speaking members of Parliament and the influence of the Māori Party have seen Māori become a language of the House in a practical as well as a theoretical sense. The number and nature of the recorded occurrences of Māori language use from 1986 onwards shows just how the status of Māori has changed in a relatively short period of time. From 1986 to 2009, over 23 years, Hansard records at least 194 uses of Māori, compared to just 36 occurrences over the previous period from 1907-1985. ${ }^{40}$ These recorded occurrences include far more use of Māori in substantive ways, over and above the shared ritual components. In fact recorded use of the language

$37 \quad$ (24 July 1985) 464 NZPD 5898.

39 Māmari Stephens, "Tame Kākā Still? Māori Members and the use of Māori language in the New Zealand Houses of Representatives" (2010) 14 LTC at 220.

40 Based on research carried out for the Legal Māori Project carried out by Phoebe Monk during the course of completing a summer research scholarship provided by the Tertiary Education Commission. 
to engage in parliamentary debate increased in an unprecedented fashion and accounts for most of the growth of Māori now seen in the Hansard record. All uses of Māori in Hansard are now followed by authorised translations, and it appears that all usages are now recorded, a far cry from the pre-1985 record, where Māori would be infrequently recorded, if at all. It is possible to say, in view of the supports in place for the Māori language in Parliament that it has become an ordinary language of the House. Perhaps in this one environment the Crown can be said, to some limited degree, to be Māori speaking.

In comparison, the Māori language is not yet an ordinary language of the New Zealand courts (with the exception of the Māori Land Court). In addition to limitations placed on the use of Māori within the Māori Language Act 1987, another disturbing development underscores this lack of real and effective protection. The District Court Rules 2009 were amended in November 2009 to be consistent with the equivalent provisions of the High Court Rules. The relevant text now reads (with the author's emphasis):

\subsection{Translation of documents into te reo Māori}

3.6.1 A person upon whom in any proceeding a document is served is entitled to receive a translation of the document into the Māori language if he or she-

(a) applies, orally or in writing, to the Registrar ...

(b) states a postal address for the service of the translation ...

(c) satisfies the Registrar that he or she is unable to read the document but could read it if it were translated into the Māori language.

The previous text of this provision gave an unqualified right of translation into Māori for served documents. The reason for this change are not publicly available, and were not recorded in the minutes of the District Rules Committee. However, as the Rules are dealing with requests for translation, the re-emergence of the criterion of disadvantage as a pre-requisite for this entitlement is apparently justified because the Māori Language Act 1987 only provides for protection of a right to use spoken not written Māori. The general right envisaged by the Tribunal in 1986 has become well and truly split. As the above excerpt shows, indeed an entitlement that had been in place has been quietly dropped.

The preceding pages have provided some examples that show that the protections in place for the language as a taonga are inconsistent and incoherent. The language right identified by the Tribunal in 1986 has been fractured in its translation into the New Zealand legal system; expressed differently in Parliament, in case-law, within the procedures governing the operations of the Courts, and within legislation. In this light, it becomes easier to see why the Tribunal in 2010 preferred the language of "treaty interests" to rights. 


\section{THE TREATY INTEREST IN TE REO MĀORI}

At [5.4.2] of the 2010 report the Tribunal stated:

Given the importance of this taonga to Māori, the Crown's protection of it clearly needs to accord with Māori preferences - and, indeed, be determined in large measure by Māori ideas. This kind of partnership or co-ownership is inherent in the Treaty. Furthermore, the Crown must see Māori and te reo as not somehow external to itself, but a core part of the society it represents - and thus a key influence over how it conducts itself. And because the Treaty of course also grants the Māori interest a greater status than simply that of a minority group within society, the Māori interest thus has a corresponding claim to resources, both fiscal and otherwise.

The 2010 report is also interesting just as much for what it does not say as for what it does say. In fact, the language of the report is telling, as it deliberately avoids using rights language, indicating a broader ambivalence about how best to conceptualise and articulate protections for the Māori language. Despite the undeniable influence and impact of the original WAI 11 report of 1986, this recent instalment avoids making explicit reference to language rights or any further contribution to rights discourse at all. In fact, as seen above, the report prefers instead to allude to the Treaty "interest" in the Māori language; a critical albeit small shift in rhetoric that raises some interesting questions about the suitability or ability of an explicit rights discourse to deal satisfactorily with the content of Treaty claims. The use of the phrase "Treaty interest" in this report locates it within an emergent Treaty discourse that eschews the language of rights and deserves some attention.

A Treaty interest notion has emerged in recent Treaty jurisprudence in regards to identifying possible remedies where Crown Treaty breaches have left behind a Treaty Interest, which is said to create an entitlement to redress for the loss of certain legal rights. ${ }^{41}$ It is doubtful however that the treaty interest referred to in the 2010 report is directly related to the Treaty Interest as expounded in the Petroleum Report. Instead it appears that the notion of Māori interests in te reo Māori enable the Tribunal to sidestep the rights discourse started by the Tribunal in 1986. In fact, a distinction between the use of the terms right and interest in Treaty discourse is not always observed, ${ }^{42}$ even within Tribunal reports. Nevertheless it is possible to view interests and rights as entailing different levels of obligation. ${ }^{43}$ The fact that the 2010 tribunal eschews the rights based language of the 1986 Tribunal may be significant, signalling an ambivalence towards rights-based Treaty discourse. There is much precedent for wariness about utilising the rights discourse to achieve effective protection for

41 For general discussion of the Waitangi Tribunal's Treaty Interest as articulated in the Petroleum Report see Huia Woods "The Treaty Interest: A New Concept in Indigenous Rights?" (Working Paper, University of Waikato, 2006).

42 See for example, use of the phrase "rights and interests" used in Matthew SR Palmer "The Treaty of Waitangi in Legislation" [2001] NZLJ 207 at 207-212.

43 For a broader discussion of rights and interests in Treaty discourse, see Ed Willis, above n 19. 
Māori custom, and indeed, for taonga. Arnu Turvey pointed to John Commons' 1924 notion of artificial selection as a way in which governments can create rights and undermine the holders of those rights at the same time: ${ }^{44}$

As Commons has outlined, at the political level the law-maker determines the outcomes of human interactions by recognising values, principles and beliefs as being valid customs or rights. In this regard, Commons equates legal rights with customs, pointing out that the state, which has sovereign powers, creates rights on the basis of its selection of some human practices over others which it prefers on the basis of the outcome of those practices. This view rejects the positivist standpoint that rights have an inherent existence that it is the role of the state to detect and protect. When broken down to this level of personal preference the cultural values of the sovereign group become paramount.

The 2010 Tribunal's plea for the Crown to become Māori speaking is an eloquent one, and may offer a clue as to why a rights discourse is subtly eschewed. If the Crown accepts its identity as Māori, and that such an identity is normal, then a rights discourse focusing on language protection for a linguistic and ethnic minority may well become unnecessary. ${ }^{45}$ However, until that acceptance occurs, a simple, effective, and well resourced framework of rights is very necessary to ensure that Māori can be heard in the civic realm, as shown by the experience in Parliament.

\section{CONCLUSION}

This paper has highlighted, even if only briefly, that the protections for the Māori language as a taonga under art II of the Treaty of Waitangi are incoherent. While the Māori language has been accepted in the legislature and in the Courts to be a taonga, the statutory rights, set out in the Māori Language Act 1987 obstruct rather than facilitate the use of Māori in legal as well as more broadly civil contexts. The statutory rights fall far short of the broader right envisaged by the Tribunal in 1986. Evidence from Parliament suggests that only an unqualified right may be effective in ensuring the language is used. Outside of Parliament however, rights to the Māori language have not been articulated or enacted in such a way that recognises the transcendent importance of the Māori language as a taonga. If, as the Waitangi Tribunal seems to be suggesting, a rights-based framework is insufficient, this paper contends an effective and coherent framework of protection and promotion for the language is necessary. Without this, Māori is unlikely to be used as a language of civic importance, let alone as a normal language of the Crown.

44 Arnu Turvey "Te Ao Māori in a 'Sympathetic' Legal Regime: The Use of Māori Concepts in Legislation" (2009) 40 VUWLR 531 at 538. See John R Commons The Legal Foundations of Capitalism (The Macmillan Company, New York, 1924) at 299. See also Richard Dawson "Artificial Selection in Colonial New Zealand" (1999) 7 Wai L Rev 4, at 4-7.

45 See also Professor Tony Angelo's article exploring the idea of attributing legal personality to taonga as a way of recognising a synthesis between the common law and Māori legal ideas. AH Angelo "Personality and Legal Culture" (1996) 26 VUWLR 395-412. 
